\title{
Differences in Body Image and Health among Sport Active and Passive Adults as a Base for School Health Education
}

\author{
Ludmila Fialová* \\ Department of Psychology, Charles University Prague, Faculty of Physical Education and Sport, Pedagogy and Didactics, 16200 \\ Prague 6, Czech Republic \\ *Corresponding author: fialova@ftvs.cuni.cz
}

Received May 20, 2014; Revised August 25, 2014; Accepted August 29, 2014

\begin{abstract}
The contribution concerns the aspects of body image, self evaluation, physical self, sport activities, health care, personal satisfaction and the possibility of improvement. The aim of the research "Body image as a part of active life style" was to learn about the importance and level of satisfaction with particular aspects of the physical and psychological self and degree of felt control and opportunity for change. The questionnaire contains 8 parts: personal data, importance and satisfaction with "My body and health" and "My thinking and feelings", self control, opportunity for change, health status, sport activities, somatic type. 866 women and 769 men were interviewed. The results show that the more physically active people value their body and health much higher and they prove a significantly higher satisfaction with monitored aspects of their own physical and psychological status. At the same time, they feel they have more control over their body and feelings. They also perceive more positively the opportunity to change, which indicates greater self confidence. The number of health complaints declared by these respondents is significantly lower than that reported by inactive participants. Control over thoughts and feelings was reported by approx. 65\% of respondents and control of body and health by even fewer respondents (approx. 60\%). There is an interesting difference in terms of control over activities for change or the ability to cope with negative things - this type of control was felt by $71 \%$ of women but only $46 \%$ of men. This result may indicate that men are less ready to deal with changes.
\end{abstract}

Keywords: body image, sport activity, physical inactivity, health care, personal satisfaction, health education

Cite This Article: Ludmila Fialová, "Differences in Body Image and Health among Sport Active and Passive Adults as a Base for School Health Education.” American Journal of Educational Research, vol. 2, no. 9 (2014): 782-787. doi: 10.12691/education-2-9-12.

\section{Introduction}

Taking care of one's body and health has become a standard part of our modern lives. While our grandparents were happy with being healthy enough to bear and bring up children, our parents' generation is spending more and more effort and money in keeping not just healthy but also good-looking and fit. Our children will face the risk of damaging both their bodies and minds by keeping drastic diets, taking food supplements designed to increase muscle mass, undergoing plastic surgeries, getting tattoos and piercing ... Why is physical perfection so important to us and why do we refuse to accept our natural selves? Psychologists and sociologists have spent years researching people's attitudes to themselves, including the very important issue of physical self image. On one hand, lack of natural physical activity leads to growing numbers of obese and ill individuals. On the other, we are confronted with a rise of eating disorders that seriously damage the human body.

\subsection{The Importance of Physical Activity for Human Health}

The recent rise of obesity has been primarily driven by lifestyle changes (persistent removal of physical activity from work as well as leisure) and dietary habits (highcalorie food with high fat content), which together results in excessive calorie intake.

An active lifestyle is characterised by an organic interaction between the individual and his or her environment. There are two aspects to this interaction biological and social (Bunc, Štilec, 2003). As one get older, the rhythm of life changes due to both the increasing age of the person and changes in the social group he or she is involved in and favoured. All this affects the person's physical, mental and social behaviour and habits that influence the development of personality, performance and identity. The overall result depends on biological (age, sex, health) as well as social determinants (cultural traditions, political and economic conditions prevailing in the society, the socioeconomic status of the individual). 
Modern technological progress and a hectic lifestyle make people grow lazier, less active and incline them to forget that physical activity is one of the factors that affect physical health and contribute to mental balance (Málková, 1992). Physical activity should have its place in the life of every individual. Physical activity has an immediate effect on metabolism and increases energy expenditure. This metabolic effect lasts for several hours after physical activity, depending on its intensity and duration. The ability to adapt to a physical load is influenced by many factors that are in mutual interaction. These factors include the initial training level, sex, total amount and distribution of bodily fat, age, genetic predisposition (Renzetti, Curran, 2005i Riegerová, Přidalová, Ulbrichová, 2006).

\subsection{Self Concept and Self Assessment}

Self concept as a person's view of himself or herself means more than just what opinions one has about her/his self. It also describes the relationship to one's self including emotional experience with cognitive, active and regulative factors. The Self is formed on a basic level of evaluation and becomes the object of opinions and attitudes.

Self assessment is a component of self concept created as a final product during socialisation. It is based and formed on social comparison and self-evaluation of one own activities (Collins, 1991; Ryan, Deci, 2000i Výrost, Slaměník, 2008). The basic self assessment criteria are formed during childhood by parents or other significant persons with the family or persons who play an important educating and parenting role. Parental support is thus the strongest predictor of self assessment (Blatný, Plháková, 2003). Peers take on the self-assessment forming role as the child grows up. However, parental support loses none of its importance during adolescence. Influences change in adult years when the individual begins professional career and founds his or her own family. At this stage, the strongest influences on self-concept are exerted by colleagues and peers as well as family members, partners, friends and children.

\subsection{The Physical Self}

Research into self-concept has recently entered the area of sports and the physical self. A number of tests have been performed to determine what role physical aspects play in our overall self-concept. The physical self is believed to be a motivating agent of our behaviour, significantly contributing to our general self-respect, mental health and well-being. The physical self-concept has been associated with sports or regular exercise that aims at keeping us fit, achieving our ideal weight, maintaining a healthy lifestyle and physical condition or rehabilitation after an injury or due a disability (Krejčí, 2008; Naul 2010).

One of the fundamental problems with self-esteem and positive self-concept is a discrepancy between one's actual body and the ideal body. It may happen that the real body and the physical ideal are diametrically different. The physical ideal is formed primarily by the social and cultural environment. The way we experience and present our bodies depends on social factors. This is important especially for the female body which is subject to precise ideas about what the ideal woman should look like. We are talking especially about external factors that convince individuals that by working hard and investing in one's body, they will be able to form their bodies according to the "ideal” (Garner, 203i Fialova, 2012).

The physical self has three basic components: look, fitness and health. Accepting one's body requires knowledge, awareness, evaluation and plans of action. The way we look is one of the factors that affect our selfesteem, which is why the behaviour and personality of our communication partners are often judged by the way they look. Physical appearance is also one of signs of social perception, which makes self-concept a part of the everyday interaction of individuals and their environment. Efforts to improve one's physical look, health and fitness may, therefore, directly or indirectly contribute to one's motivation to lead a healthy lifestyle. In general, we may say that both women and men care about the way they look, although women tend to worry about it more and are willing to spend more time and money on it.

Our modern society believes a person's image is an integral part of a lifestyle. Our relationship to our body and body-centred behaviour are also affected by our social class, gender, age and lifestyle. All this affects our perception of the body as a functional and aesthetic object. In this sense, the body is often described as the mirror of a society and a cultural product. To be attractive is one of the key trends nowadays. Feeling attractive, therefore, is important for our self-esteem. Physical attractiveness is an significant part of self-confidence, requiring that the individual accepts himself or herself and at the same time believes that others find him or her attractive. Changing one's self-concept requires, first and foremost, a change in our thinking and perception but also behavioural changes in our approach to health and beauty (Schwartz, Brownell, 2003).

\subsection{How to Improve One's Physical Self-concept}

As for the specific content of one's self-concept, it consists of various aspects of social identity (role, status, age, gender, etc.) as well as personality attributes (hobbies, activities, interpersonal style of behaviour, look, wealth, social standing, etc). Another level represents a "systematic self-assessment” (competences, value structure, etc.). Based on these factors, the individual creates a self-image, a feeling of personal autonomy and overall self-evaluation. If the individual is satisfied and happy with his/ her body, he/ she also feels stronger in control and is additional selfconfident (Fialová, 2001).

A sense of personal integrity is the fundamental condition for adaptive behaviour. To maintain a psychological integrity, one must be well motivated. Motivation regarding the self is described as selfmotivation and includes: self-consistency and selfstrengthening (Linley, 2004 ¡ Škultétyová, 2010).

The person should open up to his own feelings and accent his own opinions and wishes. If people's values are based on the reactions of others, their behaviour is motivated by a desire to conform to the wishes of others. These values then become part of the person's selfconcept and as they often express unrealistic demands, there occurs a major discrepancy between the ideal and the actual self. If the ideal and the actual self are then constantly compared, the level of self-esteem decreases. 


\section{Materials and Methods}

The objective of the "Body image as a part of active life style" research conducted by the Faculty of Physical Education and Sports of the Charles University is to determine the importance and level of satisfaction with different aspects of the physical and psychological self. We were interested to find to what degree importance, satisfaction, control and opportunity are aligned. The aim of this article is to analyse relationship with one's own body and health as well as one's own feelings and thoughts in a group of 1,635 subjects of ages ranging from 18 to 60 years (866 women and 769 men), relative to the amount of physical exercise in their daily routine $(48 \%$ were physically active and 52\% were passive). We expect our results will allow us to propose changes to long-term programmes in the area of healthy lifestyle education and help individuals arrive at a realistic self-evaluation.

\subsection{Methods Applied}

A web site was created for purposes of this research including the questionnaire "Self-concept, Quality of Life” (SQL), which consisted of 8 parts:

1. Personal data (sex, age, education, height, weight, BMI)

2. Importance and evaluation of "My body and health" (6 questions) and "My thoughts and feelings" (6 questions)

3. Satisfaction and evaluation of "My body and health" (6 questions) and "My thoughts and feelings" (6 questions)

4. Self-control (5 questions)

5. Opportunity for change (5 questions).

6. Health status (7 questions)

7. Physical activity (5 questions)

8. Body type (5 questions).

The subsection "My body and health" focuses on: look, physical activity and fitness, hygiene and care taken of one's body, nutrition and food input, physical health and sexual life. This subsection, therefore, concerns the physical self-concept, which is evaluated from several perspectives: in terms of it's importance for me, my satisfaction with it, my sense of having it under control, my chances for change.

The subsection "My thoughts and feelings" focuses on psychological aspects that reflect our feelings, our ability to learn and to self-evaluate. It focuses on our selfconfidence, attitude to problems, ability to control ourselves and deal with difficulties and stress. The questions target: self-acceptance (accepting the way I am), life without worries, fear and tension, how do I feel about

myself and what do I think about myself, mental health, mood, independence of thought and action. Once again, the personal importance of these issues is evaluated as well as my satisfaction, sense of control and chances for change.

Cronbach's $\alpha$ (internal consistency) for all respondents - men and women - ranges between 0.68 and 0.85. The content validity of the questionnaire was verified. The data were analysed using the NCSS software. The generic reliability was investigated through internal consistency of the test (particular sub dimensions of the questionnaire) by calculating of Cronbach's alpha and McDonald's omega. Cronbach's alpha acquires value between 0-1 (for dimensions $2-8$ : 0,$68 ; 0,71_{i} 0,80 ; 0,85 ; 0,70 ; 0,79 ; 0,70$ ). Coefficient omega was higher than alpha, by 5 dimensions was it close to the value 0,85 which we consider as acceptable result.

This article brings a comparison of the results between the sexes and among groups with different levels of physical activity in the weekly regime of adults.

\subsection{Subjects}

The questionnaire was answered by 866 women and 769 men who answered the questions online. The analysis works only with questionnaires that were filled in their entirety. $14 \%$ of the subjects are people under 20 years of age, $49 \%$ are in the $20-30$ age group, $16 \%$ in the $31-40$ age group, $11 \%$ in the $41-50$ age group and $9 \%$ in the $51-60$ age group. In terms of education, our respondents are very close to the actual structure of the population: $9 \%$ elementary education, 3\% vocational education, 50\% secondary-school graduates, 36\% university education, $2 \%$ on doctorate level. Since we were interested in differences between physically active and inactive populations, we chose the number of hours spent on physical activity per week as one of the key criteria. The minimum ( $0-1$ hour a week) was admitted by $18 \%$ of women and $15 \%$ of men, $2-3$ hours a week were reported by approximately a third of all respondents $34 \%$ of women and $29 \%$ of men). Active individuals (four or more hours of physical activity a week) form nearly a half of the sample (48\% of women and $55 \%$ of men) while the more passive respondents (0-3 hours of physical activity a week) consists of $52 \%$ of our female subjects and $45 \%$ of the men.

\section{Results}

\subsection{Physical and Mental Self}

Table 1. Importance and satisfaction in physical self with physically active and inactive people (scale 1-5, answers: important and very important $4+5) \%$

\begin{tabular}{|c|c|c|c|c|c|c|c|c|}
\hline & \multicolumn{4}{|c|}{ Importance } & \multicolumn{4}{|c|}{ Satisfaction } \\
\hline & \multicolumn{2}{|c|}{ Women } & \multicolumn{2}{|c|}{ Men } & \multicolumn{2}{|c|}{ Women } & \multicolumn{2}{|c|}{ Men } \\
\hline & passive & active & passive & active & passive & active & passive & active \\
\hline Look & 68 & 68 & 43 & 63 & 46 & 49 & 38 & 55 \\
\hline Phys. activity + fitness & 61 & 78 & 44 & 86 & 29 & 51 & 27 & 58 \\
\hline Hygiene, bodily care & 93 & 93 & 80 & 82 & 84 & 82 & 67 & 79 \\
\hline Nutrition & 65 & 66 & 45 & 54 & 48 & 47 & 38 & 47 \\
\hline Physical health & 88 & 89 & 80 & 87 & 54 & 58 & 50 & 59 \\
\hline Sexual life & 57 & 58 & 71 & 72 & 55 & 55 & 39 & 54 \\
\hline Overall evaluation & 432 & 452 & 363 & 444 & 316 & 342 & 259 & 352 \\
\hline
\end{tabular}


While physically active women pay the highest attention in terms of bodily care to hygiene, physical health and activity, physically passive women concentrate on hygiene, physical health and look. The most important aspects for physically active men are physical health, activity and fitness, hygiene while physically inactive men concentrate on hygiene, physical health and sexual life. Satisfaction usually received lower scores than importance. Both groups of women and men expressed the highest satisfaction with hygiene and bodily care. As for the lowest satisfaction, physically passive women and men were concerned about the amount of physical activity and fitness, while physically active women and men were mostly concerned about nutrition. In general, men considered physical aspects less important than women did and physically passive men were even less satisfied than women. Both active groups were more satisfied in general than the passive group and physically active men are the most satisfied group of all.

Table 2. Control and opportunity for change in physical and mental self with active and inactive individuals (scale 1-5, answers: important and very important $4+5) \%$

\begin{tabular}{|c|c|c|c|c|c|c|c|c|}
\hline & \multicolumn{4}{|c|}{ Control } & \multicolumn{4}{|c|}{ Opportunity } \\
\hline & \multicolumn{2}{|c|}{ Women } & \multicolumn{2}{|c|}{ Men } & \multicolumn{2}{|c|}{ Women } & \multicolumn{2}{|c|}{ Men } \\
\hline & passive & active & passive & active & passive & active & passive & active \\
\hline Body and health & 60 & 72 & 52 & 74 & 76 & 79 & 67 & 82 \\
\hline Thoughts and feelings & 66 & 69 & 57 & 72 & 66 & 69 & 72 & 66 \\
\hline Inner faith and values & 80 & 78 & 81 & 82 & 76 & 75 & 66 & 72 \\
\hline Activities for fun & 79 & 81 & 74 & 87 & 84 & 84 & 68 & 81 \\
\hline Activities for change & 68 & 75 & 39 & 52 & 70 & 76 & 61 & 71 \\
\hline Overall evaluation & 353 & 375 & 303 & 367 & 372 & 383 & 334 & 372 \\
\hline
\end{tabular}

Physically active women and men feel more in control of their body and health. Women report a significantly higher level of control over activities for fun and significantly more activities for change than men. This indicates a greater openness and awareness of own possibilities. All groups reported the highest opportunity for activities for fun. Physically active women and men believe they have greater chances of achieving all the aspects but men tend to see less opportunity than women.

By reporting little opportunity, the passive groups show certain scepticism in terms of their own contribution to change.

\subsection{Health}

We were also interested in finding differences in the subjective evaluation of health, health problems and health-related care of one's body.

Table 3. Health complaints (\%)

\begin{tabular}{|c|c|c|c|c|c|c|}
\hline & & Women & & & Men & \\
\hline & passive & active & general & active & passive & general \\
\hline Sleep disorders & 17 & 11 & 28 & 28 & 20 & 48 \\
\hline Fatigue & 23 & 9 & 32 & 30 & 19 & 49 \\
\hline Headache & 13 & 10 & 23 & 11 & 11 & 22 \\
\hline Backache & 26 & 22 & 48 & 43 & 37 & 80 \\
\hline Digestive complaints & 17 & 14 & 31 & 24 & 13 & 37 \\
\hline Overall weakness & 18 & 11 & 29 & 25 & 17 & 42 \\
\hline Total complaints & 114 & 77 & 191 & 161 & 117 & 278 \\
\hline
\end{tabular}

The most commonly reported health complaint was backache, which was stated by nearly a half of all women and as many as $80 \%$ of men. Fatigue, digestive complaints and sleep disorders were quite common, too. Men have more health complaints than women (except headache).

Physically active men and women reported significantly less complaints than the passive groups. The biggest difference was found in terms of fatigue and, in men, in terms of digestive complaints. The positive results achieved by the physically active respondents are conclusive.

Table 4. Healthcare in physically active and passive respondents (\%)

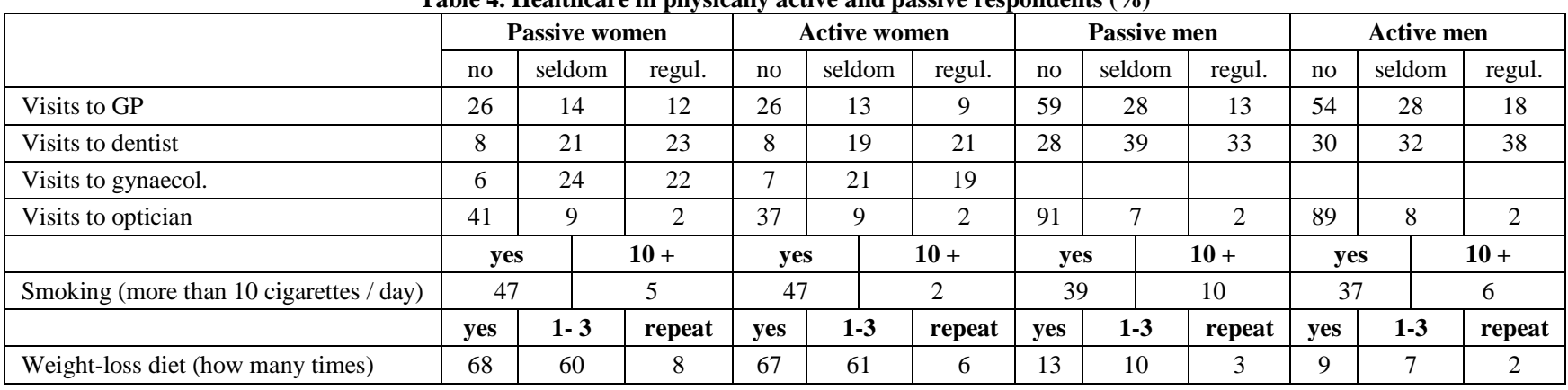

In terms of awareness of the importance of regular visits to doctors and in terms of health-conscious behaviour, no significant differences were found between the active and passive group, with the exception of the amount of physical activity in the weekly regime. The number of smokers among active and passive respondents is similar, although physically active individuals seem to smoke fewer cigarettes a day. Weight-loss diet is not frequent at men, but more then $60 \%$ of women declare 
using of reducing diet. The physically active groups report lower numbers but the differences are not significant.

\section{Discussion}

The objective of the article was to analyse the relationship one has to his or her own body and health, thoughts and feelings based on sorting criteria including sex and the amount of physical activity in the weekly regime. Our results indicate that self-concept is largely determined by the sex of the person rather than by other circumstances. Like other researchers (Fox, 1990, Grogan, 2000, Higgins, 1997, Fialova, 2006), we found that selfimage and the attitude one takes to one's self and one's body depends primarily on the sex, to some degree on physical activity and less so on age, education and other factors. The results reported in this article confirm the importance of physical activity for satisfaction with one's look, health, function and performance of one's body. Physically more active groups (especially men who ascribe more importance to physical activity and performance) appreciate the body and health more, they are also significantly happier with the monitored aspects of their physical and mental state. At the same time, they feel more in control of their body and feelings. Active people tend to see more opportunity for change, which indicates a higher level of self-confidence. Furthermore, the number of health complaints reported by these respondents is significantly lower than that reported by inactive participants.

A surprising finding was that the attendants of the research (especially women) declared greater importance of psychological aspects (thoughts and feelings) than physical aspects (body and health). This might be influenced by stress, work overload, tension and worries that are part of the everyday lives of us all. The importance of mental and physical health was recognised by more than $80 \%$ of respondents. In terms of the psychological aspects, the most important factors were: life without fear and tension, independence of thought and action, feeling good about self. In terms of physical aspects, the most important factors were hygiene and bodily care, health. Physical activity and fitness were considered more important than look and nutrition. Physical health, hygiene and activity are of more importance for active individuals, while passive participants are more concerned about hygiene, physical health and looking. They replaced physical activity by looks in this value system, which may explain why physically inactive people tend to be more susceptible to advertisements promoting products that promise miraculous changes to the body and looks without much effort.

Evaluation of satisfaction appeared rather different. Overall, satisfaction was lower than the reported importance (lower scores were shown on all aspects by both men and women). In psychological terms, men and women were the least satisfied in terms of life free of tension and worries and the way they feel about themselves and what they think of themselves. In terms of physical aspects, the least satisfaction was reported on activity and fitness as well as looks and nutrition in women. This dissatisfaction may lead women to adopt behaviour that is commendable in terms of health but, on the other hand, lack of understanding and susceptibility to media pressure may lead women to believe in the impossible. Once the promised results fail to materialise, even more dissatisfaction may be felt. Women are considered more susceptible to advertising than men (even more so if they are young and have less education) and many companies in special concern on health and attractiveness take clever advantage of this. Men complained the most about nutrition, sexual life and looks. The biggest dissatisfaction in psychological terms was reported regarding mental health and independence of action. Hygiene and bodily care were mentioned in physical terms.

The sense of having control over one's self also plays a certain role in self-concept and self-confidence. The results indicate difference in the control over physical and mental aspects felt by men and women. Women feel they have their thoughts and feelings under control while men consider in control of their bodies. The respondents realise that they have a great choice of activities for fun (a total of $80 \%$ of respondents recognised this). Control over thoughts and feelings were reported by approx. 65\% of respondents and control of body and health by even fewer respondents (approx. 60\%). There is an interesting difference in terms of control over activities for change or the ability to cope with negative things - this type of control was felt by $71 \%$ of women but only $46 \%$ of men. This result may indicate that men are less ready to deal with changes.

Opportunity for change or chance of achieving change was identified on a larger scale than the feeling of having control. Women and men see the most opportunities for activities for fun (over 80\%). A surprisingly high number of respondents notice opportunity for bodily care and health. A total of $76 \%$ of passive, $79 \%$ of active women, $67 \%$ of passive and $82 \%$ of active men believe they can achieve positive change in this respect if they try. Men feel a great discrepancy between opportunity for (61\% passive and $71 \%$ active men) and control over (39\% passive and 52\% active men) activities for change. Maybe respondents believe that they have the chances and opportunities but they do not take advantage of them and they are unable to take control of their body and health.

\section{Conclusion}

Our research data confirmed the benefits of physical activity for mental and physical health. The active life style is essential nowadays. The education systems should be in the front line of the fight against the obesity epidemic. The main task of health education is to teach the yang generation preventive behaviour. The children on every level should understand profits of physical activity, healthy nutrition, well being...

The entire society is now under media pressure, which demands that everybody take good care of their bodies without respecting individual possibilities and limits faced by every individual. Our task is to educate people to take qualified measures to improve their health and accept themselves the way they are. Success and socioeconomic prosperity can be achieved only by a healthy society. A healthy society is composed of healthy individuals who recognise their own value, who accept themselves and who work on their own growth and development with their own individual limits. 


\section{Acknowledgement}

This study was supported by the Grant Agency „VZ MŠMT ČR MSM 0021620864“" and Grant Agency of the Czech Republic „GA CR 406/05/0564“ and „PRVOUK $15 “$.

\section{References}

[1] BLATNÝ, M., PLHÁKOVÁ, A. Temperament, inteligence, sebepojetí. Nové pohledy na tradiční témata psychologického výzkumu. Brno: Psychologický ústav AV ČR, 2003. 150 s.

[2] BUNC, V., ŠTILEC, M. Tělesné složení jako indikátor aktivního životního stylu seniorek. Česká kinantropologie, 2007. 11, 3, s. $17-25$.

[3] COLLINS, M. E. Body Figure Perception and Preferences among adolescent Children. International Journal of eating Disorders, 1991. 2, p. 199-208.

[4] FIALOVÁ, L. Body image jako součást sebepojetí člověka. Praha: Karolinum, 2001.

[5] FIALOVÁ, L. Moderní body image. Jak se vyrovnat s kultem štíhlého těla. Praha: Grada, 2006.

[6] FIALOVÁ, L. Pojetí vlastního těla. Zdraví, zdatnost, vzhled. Praha: Karolinum 2012.

[7] FOX, K. R. The Physical Self-Perception Profile Manual. De Kalb, IL: Northern Illinois University Office for Health Promotion, 1990.
[8] GARNER D.M.: Body image and anorexia nervosa. In: Cash T.F., Pruzinsky T. (Eds.) Body image: A handbook of theory, research, and clinical practice. N.Y.: The Guilford Press, 2003, p. 295-303.

[9] GROGAN, S. Body image - psychologie nespokojenosti s vlastním tělem. Praha: Grada, 2000.

[10] HIGGINS, E. T. Self-discrepancy: Theory relating self and affect. 1987.

[11] KREJCI, M. Factors of Self-Control and Self-Esteem in Overweight Reduction. Ceske Budejovice: JU, 2008.

[12] LINLEY, P. A., JOSEPH, S. (Eds.) Positive psychology in practice. New Jersey: Wiley, Hoboken, 2004.

[13] MÁLKOVÁ, I.. Jak hubnout pomalu, ale jistě. Praha: Avicenum, 1992.

[14] NAUL, R. Gesunde Kinder in gesunden Komunen. Essen, 2010.

[15] RENZETTI, C. M., CURRAN, D. J. Ženy, muži a společnost. Praha: Nakladatelství Karolinum, 2005.

[16] RIEGEROVÁ, J, PŘIDAlOVÁ, M., ULBRICHOVÁ, M. Aplikace fyzické antropologie v tělesné výchově a sportu. Hanex: Olomouc, 2006.

[17] RYAN, R. M., DECI, E. L. Self determination theory and the facilitation of intrinsic motivation, social development, and wellbeing. American Psychologist, 2000. 55, p. 68-78.

[18] SCHWARTZ, M. B., BROWNELL, K. D.: Obesity and body image. Body Image, 2003, vol. 1, p. 43-56.

[19] ŠKULTETYOVÁ, L. Analýza účinků pohybového programu na korekci těla a tělesné sebepojetí. DP, Praha: UK FTVS, 2010.

[20] VÝROST, J., SLAMĚNÍK, I. Sociální psychologie. Praha: Grada, 2008. 